\title{
Status boundary enforcement and the categorization of black-white biracials
}

\section{Citation}

Ho, Arnold K., Jim Sidanius, Amy J.C. Cuddy, and Mahzarin R. Banaji. 2013. “Status Boundary Enforcement and the Categorization of Black-white Biracials." Journal of Experimental Social Psychology 49 (5) (September): 940-943.

\section{Published Version}

doi:10.1016/j.jesp.2013.04.010

\section{Permanent link}

http://nrs.harvard.edu/urn-3:HUL.InstRepos:17416812

\section{Terms of Use}

This article was downloaded from Harvard University's DASH repository, and is made available under the terms and conditions applicable to Open Access Policy Articles, as set forth at http:// nrs.harvard.edu/urn-3:HUL.InstRepos:dash.current.terms-of-use\#OAP

\section{Share Your Story}

The Harvard community has made this article openly available.

Please share how this access benefits you. Submit a story.

\section{Accessibility}


Status Boundary Enforcement and the Categorization of Black-White Biracials

Arnold K. Ho, Department of Psychology, Colgate University, Hamilton, NY, USA

Jim Sidanius, Departments of Psychology and of African and African American Studies, Harvard University, Cambridge, MA, USA

Amy J. C. Cuddy, Harvard Business School, Harvard University, Boston, MA, USA

Mahzarin R. Banaji, Department of Psychology, Harvard University, Cambridge, MA, USA

\section{CORRESPONDING AUTHOR:}

Arnold K. Ho

Colgate University

13 Oak Drive

Hamilton, NY 13346

aho@colgate.edu 


\begin{abstract}
Individuals who qualify equally for membership in more than one racial group are not judged as belonging equally to both of their parent groups, but instead are seen as belonging more to their lower status parent group. Why? The present paper begins to establish the role of individual differences and social context in hypodescent, the process of assigning multiracials the status of their relatively disadvantaged parent group. Specifically, in two experiments, we found that individual differences in social dominance orientation - a preference for group-based hierarchy and inequality_-interacts with perceptions of socioeconomic threat to influence the use of hypodescent in categorizing half-Black, half-White biracial targets. Importantly, this paper begins to establish hypodescent as a "hierarchy-enhancing" social categorization.
\end{abstract}

Keywords: hypodescent, social dominance orientation, intergroup threat, hierarchy maintenance 
Status Boundary Enforcement and the Categorization of Black-White Biracials "In the 1850 s the strong fears of abolition and slave insurrections resulted in growing hostility toward miscegenation, mulattoes, concubinage, passing, manumission, and of the implicit rule granting free mulattoes a special, in-between status in the lower south.... Thus, the South came together in strong support of [the rule of hypodescent] in order to defend slavery..."

Davis, 1991, p. 49

The categorization and perception of multiracial individuals has profound implications for the permeability and stability of extant racial boundaries. Indeed, psychologists, political scientists, and sociologists alike have debated the implications of interracial marriage and mixed race for social stratification in America (e.g., Alba \& Nee, 2003; Ho, Sidanius, Levin, \& Banaji, 2011; Hochschild, Weaver, \& Burch, 2012; Lee \& Bean, 2004; Sears \& Savalei, 2006). Yet, to understand whether mixed race will transform the American racial hierarchy, one must understand how mixed-race individuals are categorized and perceived. In the U.S., the treatment of mixed-race individuals, Black-White in particular, has historically been governed by a rule of hypodescent, whereby biracials are judged as belonging more to their lower status parent group. Social psychologists have recently found that this rule still governs how Americans judge biracials in the $21^{\text {st }}$ century (Ho et al., 2011; Peery \& Bodenhausen, 2008). However, little is known about why this bias in our categorization and perception exists - that is, more research is needed to establish the social psychological underpinnings of hypodescent (Ho et al., 2011). In the present paper, we focus on how social dominance orientation-individual differences in the preference for group based hierarchy and inequality — and realistic intergroup threat influence the use of hypodescent.

Social dominance orientation (SDO) predicts a wide range of intergroup phenomena, ranging from support for aggression against low status groups to opposition to social policies that 
would bring about greater equality (Ho et al., 2012; Kteily, Ho, \& Sidanius, 2012; Pratto, Sidanius, Stallworth, \& Malle, 1994). Individuals high in SDO endorse a variety of hierarchyenhancing ideologies - i.e., beliefs that lend legitimacy to the extant social system — and engage in a variety of behaviors intended to maintain existing systems of social stratification. Given the potential for the rule of hypodescent to maintain existing status boundaries, we theorize that SDO should also predict the use of hypodescent in judging biracials. In other words, hypodescent may in some circumstances operate as a hierarchy-enhancing social categorization.

However, not all situations or historical circumstances require the active policing of group boundaries. As the sociologist James Davis notes in the opening passage, Black-White biracials were tolerated for a time in American history and granted a "special, in-between status." It was only when the institution of slavery was threatened that dominant Whites began to enforce the rule of hypodescent. Empirical work has similarly shown that social dominance drives can be "activated" by situations in which the hierarchy is perceived to be unstable (Knowles, Lowery, Chow, \& Hogan, 2009; Thomsen, Green, \& Sidanius, 2008). Thomsen et al. (2008) demonstrated that perceptions that immigrants were trying to assimilate to the American mainstream, and thus "trespass" existing group boundaries, led Americans high in SDO to support immigrant persecution. Relatedly, Knowles et al. (2009) found that perceptions of intergroup threat led individuals high in SDO to endorse versions of colorblind ideology that could potentially justify the status quo. Importantly, in both studies, SDO was not related to intergroup bias or system justifying beliefs in the absence of an intergroup threat. Thus, it appears that anti-egalitarians strategically engage in costly boundary maintenance behaviors under circumstances that warrant the expenditure of such mental and material resources - i.e., when the existing social order is threatened. Furthermore, given that systems of group based 
inequality tend to be stable and resistant to change (Sidanius \& Pratto, 1999, p. 37), the default may be to assume stability; thus evidence of instability may be needed to induce anti-egalitarians to behave and think in hierarchy-enhancing ways. Building on this theorizing and research, we reasoned that perceptions of realistic threat may similarly interact with SDO to influence the use of hypodescent. In two experiments, we manipulate perceptions of threat to examine whether this triggers individuals high in SDO to use the rule of hypodescent to a greater extent-i.e., whether threat moderates the relationship between SDO and hypodescent.

\section{Experiment 1}

In Experiment 1, we begin our exploration of whether SDO and threat interact to influence the use of hypodescent by exposing Whites to statements concerning realistic threats posed by Blacks. If hypodescent represents a hierarchy-enhancing social categorization, individuals who are high in SDO and who are primed with the idea that Blacks represent a growing socioeconomic threat should be most likely to judge Black-White biracials as being relatively Black.

\section{Methods}

One-hundred and sixty three White Americans were recruited through Amazon's MTurk and passed an attention check (Oppenheimer, Meyvis, \& Davidenko, 2009). ${ }^{1}$ Eighty-four were randomly assigned to a realistic threat condition, in which they were exposed to ideas suggesting that African Americans represent a growing socioeconomic threat (i.e., they had to complete a measure of realistic threat; Stephan et al., 2002). Because the items of this measure constituted our manipulation of threat, we were not interested in responses to these items (Morrison \& Ybarra, 2008). All participants completed the $\mathrm{SDO}_{6}$ measure $(\alpha=.94 ; m=2.38, S D=1.16$; Pratto et al., 1994); participants in the control condition were simply directed to the SDO 
measure without exposure to the ideas concerning realistic threat. ${ }^{2}$ After the SDO measure, participants indicated whether they believed a half-Black, half-White biracial target was relatively Black, equally Black and White, or relatively White on a seven-point scale $(m=4.09$, $S D=.42$; reverse-coded such that higher scores indicate greater hypodescent).

Results

To explore the interaction between SDO and realistic threat in predicting hypodescent, we mean-centered SDO and regressed hypodescent on SDO, threat, and the SDO $\times$ threat interaction term. This analysis revealed a main effect for threat $(B=.14, S E B=.07, \beta=.16, t=$ $2.13, p=.03)$ and more importantly, a significant interaction between SDO and threat $(B=.13$, $S E B=.06, \beta=.27, t=2.31, p=.02$; see Figure 1). A simple slopes analysis revealed that in the control condition, SDO was unrelated to hypodescent $(B=-.05, S E B=.04, \beta=-.13, t=-1.09$, $n s)$, whereas in the realistic threat condition, SDO was significantly positively related to hypodescent $(B=.08, S E B=.04, \beta=.23, t=2.28, p=.02)$. We also examined the simple slopes with SDO as the moderator. This revealed that among those who are one SD below the mean on SDO, there was no effect of threat $(B=-.01, S E B=.09, \beta=-.02, t=-.15, n s)$.

However, among those who were at the mean on $\operatorname{SDO}(B=.14, S E B=.07, \beta=.16, t=2.13, p=$ $.03)$ and $1 S D$ above the mean in $\operatorname{SDO}(B=.29, S E B=.09, \beta=.35, t=3.12, p=.00)$, the threat manipulation had a significant effect on hypodescent. These results begin to demonstrate that situations in which intergroup threat is salient can induce individuals high in SDO to use a rule of hypodescent.

\section{Experiment 2}

In Experiment 2, we aim to further demonstrate that situations that suggest instability in the hierarchy — a salient intergroup threat—can lead high SDO individuals to use the rule of 
hypodescent. In particular, we aim to conceptually replicate our findings using a vignette manipulation that either reports that Blacks have made significant gains in business, education, and politics (the threat condition), or that Blacks have not made any progress. In addition, hypodescent is more broadly defined by the use of a composite measure in this study. Furthermore, SDO is measured first here to further confirm that measuring it after the threat manipulation did not influence the pattern of results in Experiment 1.

\section{Methods}

Fifty-seven White Americans were recruited through Amazon's MTurk and passed an attention check (Oppenheimer et al., 2009). ${ }^{3}$ All participants began the study by completing the $\mathrm{SDO}_{6}$ measure $(\alpha=.97, m=2.57, S D=1.33$; Pratto et al., 1994). Participants were then randomly assigned to a realistic threat condition, in which they were exposed to a vignette suggesting that African Americans represent a growing socioeconomic threat $(n=31)$, or to a condition that suggested no progress in the status of Blacks. For example, part of the vignette described Blacks' progress in business:

...a 2011 survey of 25 Fortune 500 companies revealed that the number of African Americans in managerial positions at these companies has increased dramatically [remained low and not increased] since 2000. In 2000, Blacks represented 5\% of all employees with managerial responsibilities in the surveyed companies. Today, they represent $18 \%$ [4.6\%] of all managers. During the same period, the percentage of Whites in managerial positions has decreased from $75 \%$ to $63 \%$ [remained steady]....

All participants then completed a 4-item measure of hypodescent asking if they believe a biracial target will look like, behave like, or "fit in better with" Blacks or Whites $(\alpha=.65, m=4.39, S D$ 
$=.61 ; 7$-point scale reverse-coded such that higher scores indicate greater hypodescent). Finally, participants completed the hypodescent measure used in Experiment $1(m=4.20, S D=.44)$.

\section{Results}

To explore the interaction between SDO and threat in predicting responses to the fouritem composite hypodescent measure we created for this study, we again mean-centered SDO, and regressed hypodescent on SDO, threat, and the SDO $\times$ threat interaction term. This revealed a clear pattern consistent with the findings in Experiment 1. That is, although the main effects were not significant, the $\mathrm{SDO} \times$ threat interaction was significant $(B=.34, S E B=.11, \beta=.59, t$ $=2.93, p=.01$; see Figure 2). Furthermore, a simple slopes analysis revealed that in the control condition, SDO was unrelated to hypodescent $(B=-.08, S E B=.09, \beta=-.18, t=-.91, n s)$, whereas in the threat condition, SDO was significantly positively related to hypodescent $(B=$ $.25, \operatorname{SE} B=.07, \beta=.55, t=3.70, p=.00)$. We also examined the simple slopes for this interaction with SDO as the moderator. This revealed that at $1 S D$ below the mean on SDO, the threat manipulation did not influence hypodescent $(B=-.18, S E B=.21, \beta=-.14, t=-.83, n s)$. At the mean of SDO, the threat manipulation had a marginally significant effect on hypodescent $(B=.27, S E B=.14, \beta=.22, t=1.87, p=.07)$. Most importantly and consistent with our hypothesis, at one $S D$ above the mean on SDO, the threat manipulation significantly affected hypodescent $(B=.72, S E B=.21, \beta=.59, t=3.42, p=.00)$. In addition, we conducted the same analysis using the hypodescent measure used in Experiment 1, and obtained an identical pattern of results (see supplementary materials). Thus, our second experiment further demonstrates that situations in which intergroup threat is salient can induce individual high in SDO to use a rule of hypodescent. It is noteworthy that these results replicate our finding from Experiment 1 using both the same measure of hypodescent and a novel measure of hypodescent capturing various 
dimensions of hypodescent. Future research should investigate this broadened conception of hypodescent further by measuring the various dimensions (phenotype, behavior, and "fit") in greater depth.

\section{General Discussion}

Consistent with our hypothesis, in two experiments, SDO interacted with realistic intergroup threat to predict the use of hypodescent in judging a Black-White biracial target. That is, participants who are relatively high in SDO and who are induced to believe that African Americans represent a realistic threat are more likely to see a Black-White biracial person as Black.

By integrating previous theorizing and research on social dominance theory and intergroup threat theory and bringing it to bear on the phenomenon of hypodescent, this paper simultaneously builds on the large body of literature documenting the predictive power of SDO, demonstrates that individuals seeking to preserve the hierarchical status quo are sensitive to social context (see also Guimond et al, in press), and illuminates one critical reason why people may exhibit a bias in their categorization and perception of multiracials.

In demonstrating how SDO interacts with threat to influence the use of hypodescent, the present research demonstrates the utility of integrating individual differences research with approaches emphasizing the social context in order to develop a richer understanding of the dynamics of intergroup relations (see Thomsen et al., 2008). It also provides another demonstration of a principle long espoused by social dominance theorists - that social context can influence SDO's relationship with other intergroup phenomena (e.g., Pratto, Sidanius, \& Levin, 2006). In other words, it is precisely those situations that threaten the extant social order 
that are likely to motivate individuals who are relatively high in SDO to act to preserve the status quo.

Importantly, the current studies begin to identify moderators of hypodescent, and in doing so, also help to explain why hypodescent is not always observed (e.g., Chen \& Hamilton, 2012). Since group-based hierarchies are relatively stable-e.g., U.S. Census data shows that between 1965 and 2010, household income gaps between Whites, Latinos, and Blacks did not change in spite of the Civil Rights Movement (DeNavas-Walt, Proctor, \& Smith, 2011) — it may be that social perceivers do not ordinarily perceive the social hierarchy to be changing. It may take clear evidence that the hierarchy is under siege to engage anti-egalitarian motives and biases such as the rule of hypodescent. That hypodescent is used to judge biracials precisely when the status quo is threatened suggests the power of this bias to reify existing group boundaries, and thereby relegate biracials to the discriminatory treatment faced by their minority parents.

Other cognitive, attitudinal, individual difference, and contextual factors undoubtedly play a role in hypodescent as well (Ho et al., 2011). For example, Halberstadt, Sherman, \& Sherman (2011) demonstrated that basic mechanisms governing how we learn novel facial features may lead the features of racial minorities to be more salient when combined with the features of racial majority group members. Furthermore, Castano, Yzerbyt, Bourguignon, and Seron (2002) have discovered that individuals who identify strongly with their ingroup take a relatively long time to categorize racially ambiguous faces and are more likely to reject such faces as belonging to the ingroup. This effect, also known as "ingroup overexclusion," should be related to hypodescent and suggests that ingroup identity may play a role in hypodescent as well. Other motivational factors, such as racial prejudice, may further contribute to hypodescent. To enrich our understanding of the psychology of hypodescent, future research should continue to 
examine both cognitive and social underpinnings of how we categorize and perceive multiracials. It may also be fruitful to consider how social and cognitive antecedents of hypodescent may moderate or mediate one another.

Although the current work establishes that individuals high in SDO indeed use the rule of hypodescent to a greater extent when faced with the prospect that the hierarchy is changing, further work will help establish the precise mechanism that drives this effect. Future research should seek to establish whether this bias is enhanced due to threshold setting (e.g., a lower threshold being used to judge someone as minority), differential attention to minority phenotypic features, differential willingness to use the minority label, or some other mechanism.

Future research on SDO, intergroup threat, and hypodescent should also examine other forms of threat (e.g., symbolic threat), other forms of categorization and perception (e.g., visual perception of biracials), and other multiracial target groups. It would be interesting, for example, if SDO interacts with threats to the cultural hierarchy as well to influence the use of hypodescent. While more research should help establish the limiting conditions of the phenomenon uncovered in this paper, the current findings, grounded in prior theorizing in social dominance theory and intergroup threat theory, begin to establish hypodescent as a hierarchy-enhancing social categorization. 


\section{Acknowledgements}

This research was supported by a Colgate University research grant awarded to Arnold K. Ho. We thank Suzanne Freedberg and Kelsey John for research assistance. We also thank members of the Sidanius and Banaji Labs at Harvard University, as well as students in the Spring 2013 Psychology of Prejudice and Racism seminar at Colgate University for helpful feedback. Correspondence concerning this article should be addressed to Arnold K. Ho, Department of Psychology, Colgate University, 13 Oak Drive, Hamilton, NY 13346. Email: aho@colgate.edu 


\section{References}

Alba, R. D., \& Nee, V. (2003). Remaking the American mainstream: Assimilation and contemporary immigration. Cambridge: Harvard University Press.

Castano, E., Yzerbyt, V., Bourguignon, D., \& Seron, E. (2002). Who may enter? The impact of in-group identification on in-group/out-group categorization. Journal of Experimental Social Psychology, 38, 315-322.

Chen, J.M. \& Hamilton, D.L. (2012). Natural ambiguities: Racial categorization of multiracial people. Journal of Experimental Social Psychology, 48(1), 152-164.

Davis, F. J. (1991). Who is black? One nation's definition. University Park: Pennsylvania State University Press.

DeNavas-Walt, C., Proctor, B. D., \& Smith, J. C. (2011). Income, Poverty, and Health Insurance Coverage in the United States: 2010 (Current Population Reports, P60-239). Washington, DC: U.S. Government Printing Office.

Guimond, S., Crisp, R., De Oliveira, P., Kamiejski, R., Kteily, N., Kuepper, B., Lalonde, R., Levin, S., Pratto, F., Tourgas, F., Sidanius, J., \& Zick, A. (in press). Diversity policy, social dominance and intergroup relations. Journal of Personality and Social Psychology.

Halberstadt, J., Sherman, S. J., \& Sherman, J. W. (2011). Why Barack Obama is Black: A cognitive account of hypodescent. Psychological Science, 22(1), 29-33.

Hochschild, J. L., Weaver, V., \& Burch, T. (2012). Creating a new racial order: How immigration, multiracialism, genomics, and the young can remake race in America. Princeton, New Jersey: Princeton University Press.

Ho, A. K., Sidanius, J., Levin, D. T., \& Banaji, M. R. (2011). Evidence for hypodescent and 
racial hierarchy in the categorization and perception of biracial individuals. Journal of Personality and Social Psychology, 100(3), 492-506.

Kahn, K., Ho, A. K., Sidanius, J., \& Pratto, F. (2009). The space between us and them: Perceptions of status differences. Group Processes and Intergroup Relations, 12(5), 591604.

Knowles, E. D., Lowery, B. S., Hogan, C. M., \& Chow, R. M. (2009). On the malleability of ideology: Motivated construals of color blindness. Journal of Personality and Social Psychology, 96(4), 857-869. doi:10.1037/a0013595

Kteily, N., Ho, A. K., \& Sidanius, J. (2012). Hierarchy in the mind: The predictive power of social dominance orientation across social contexts and domains. Journal of Experimental Social Psychology, 48, 543-549.

Lee, J., \& Bean, F. D. (2004). America's changing color lines: Immigration, race/ethnicity, and multiracial identification. Annual Review of Sociology, 30, 221-42.

Morrison, K. R., \& Ybarra, O. (2008). The effects of realistic threat and group identification on social dominance orientation. Journal of Experimental Social Psychology, 44, 156-163.

Oppenheimer, D. M., Meyvis, T. \& Davidenko, N. (2009). Instructional manipulation checks: Detecting statistical power. Journal of Experimental Social Psychology, 45, 867-872.

Peery, D., \& Bodenhausen, G. (2008). Black + White = Black: Hypodescent in reflexive categorization of racially ambiguous faces. Psychological Science, 19(10), 973-977.

Pratto, F., Sidanius, J., \& Levin, S. (2006). Social dominance theory and the dynamics of intergroup relations: Taking stock and looking forward. European Review Of Social Psychology, 17, 271-320. doi:10.1080/10463280601055772

Pratto, F., Sidanius, J., Stallworth, L. M., \& Malle, B. F. (1994). Social dominance orientation: A 
personality variable predicting social and political attitudes. Journal of Personality and Social Psychology, 67(4), 741-763. doi:10.1037/0022-3514.67.4.741

Sears, D. O., \& Savalei, V. (2006). The political color line in America: Many “peoples of color" or black exceptionalism? Political Psychology, 27(6), 895-924.

Stephan, W. G., Boniecki, K. A., Ybarra, O., Bettencourt, A., Ervin, K. S., Jackson, L. A., ... Renfro, C. L. (2002). The role of threats in the racial attitudes of Blacks and Whites. Personality and Social Psychology Bulletin, 28(9), 1242-1254.

doi:10.1177/01461672022812009

Thomsen, L., Green, E. T., \& Sidanius, J. (2008). We will hunt them down: How social dominance orientation and right-wing authoritarianism fuel ethnic persecution of immigrants in fundamentally different ways. Journal Of Experimental Social Psychology, 44(6), 1455-1464. doi:10.1016/j.jesp.2008.06.011 


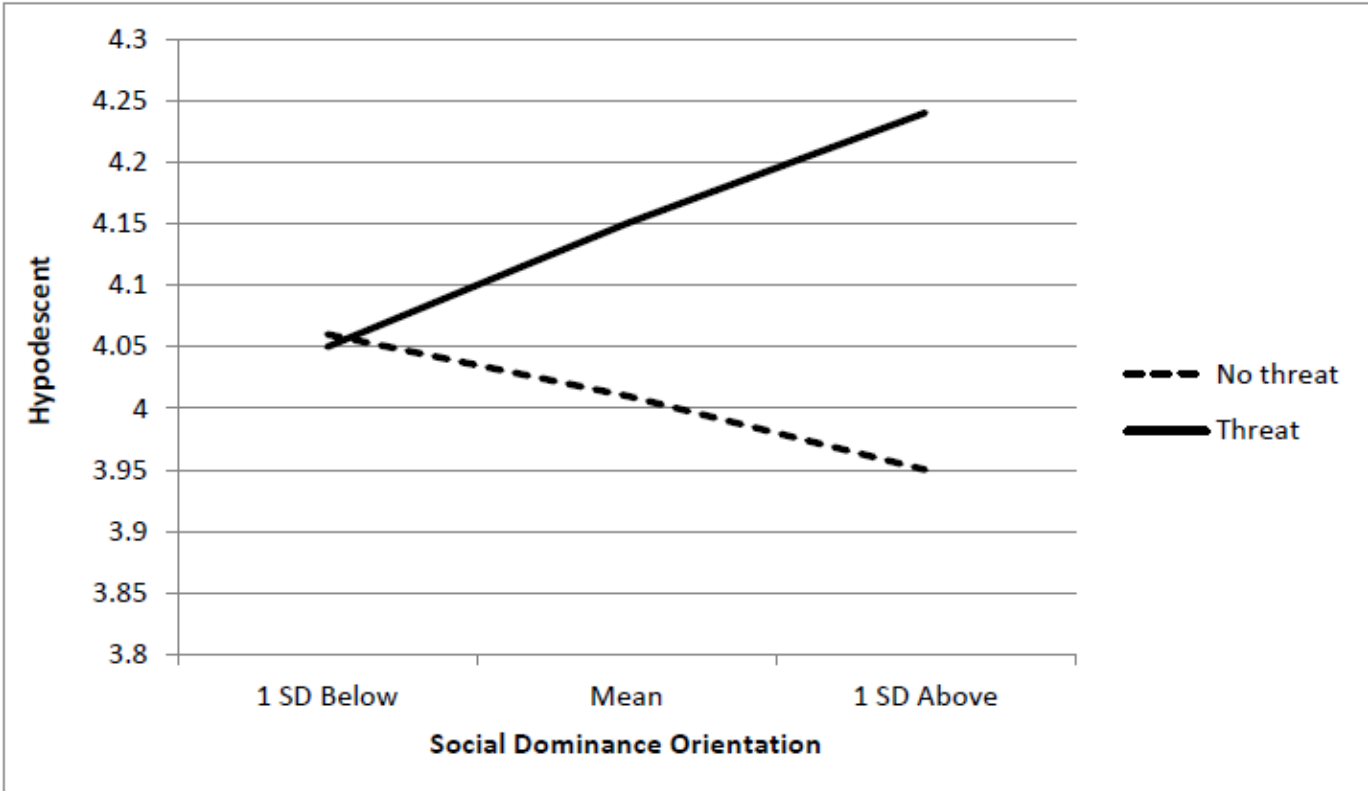

Figure 1. The interaction between social dominance orientation and threat in predicting hypodescent in Experiment 1. 


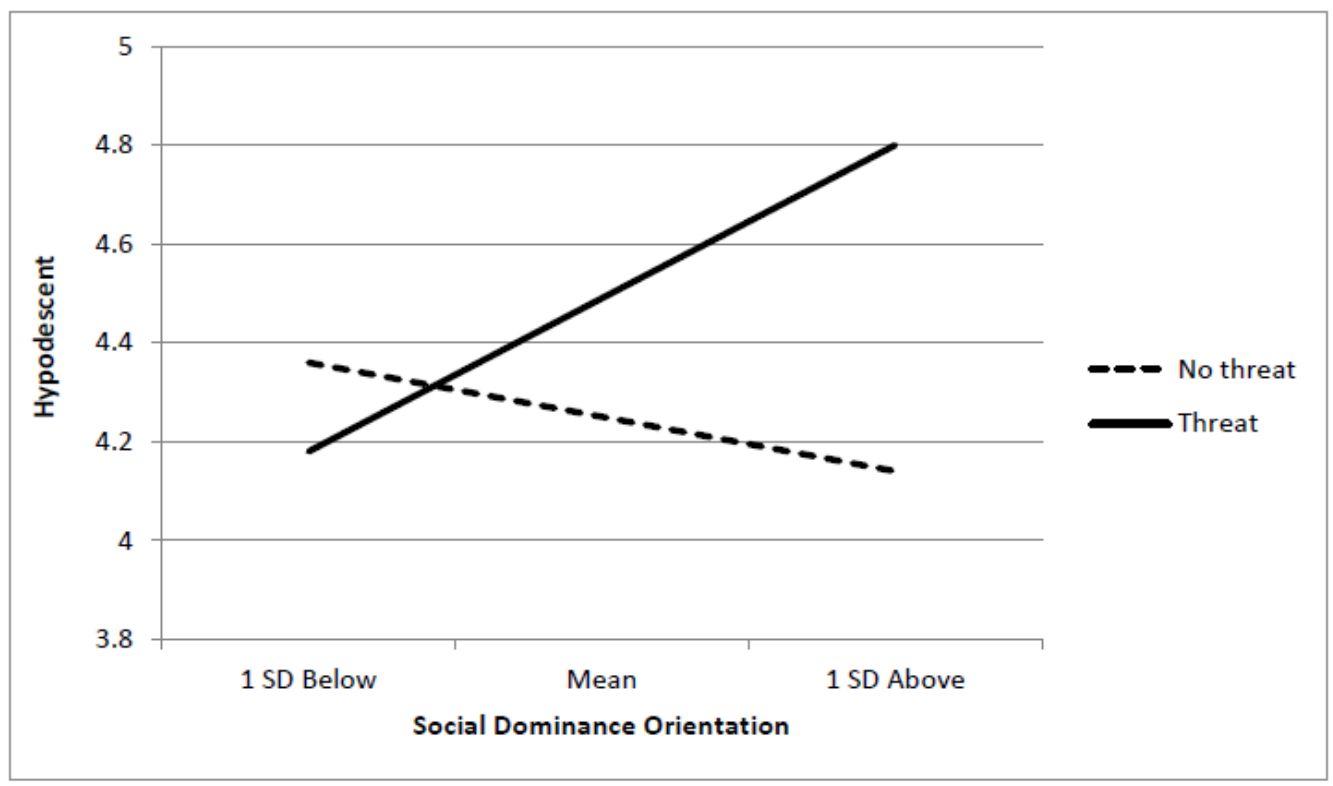

Figure 2. The interaction between social dominance orientation and threat in predicting hypodescent in Experiment 2 . 
Highlights

- This paper demonstrates that individual differences and social context interact to influence how we categorize biracials.

- We show that the rule of hypodescent is used to enforce group boundaries.

- Anti-egalitarians are shown to strategically engage in hierarchy maintenance.

\footnotetext{
${ }^{1}$ We focus on Whites, the highest status group in the U.S. (Kahn, Ho, Sidanius, \& Pratto, 2009), as previous research has found that the relationship between SDO and hierarchy-enhancing beliefs is strongest among high status groups (e.g., Sidanius, Levin, \& Pratto, 1996). 69\% passed the attention check, a proportion that is consistent with other studies using conceptually similar attention checks (e.g., Oppenheimer et al., 2009). ${ }^{2}$ Although SDO was measured after the threat manipulation, the mean level of SDO was not different across conditions $(t(161)=-1.26, n s)$.

${ }^{3} 85 \%$ passed the attention check.
} 